\section{3. 結言 -}

維維を少しつ゚つその位置をずらせて長さの方向 に順次配列し，とれによりを加えたるのと考えられる が，とのずれの最高値はどの程度か，この問題につき。 從來諸家の舉げる數値に基き計算し, 大略の值を求め た。計算は種々の數值が與えられている綿系扎よび梳

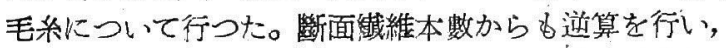
檢討した。との瀻維末端間可能最大距離は繊維長大な るに從い，直線的潧加し，をの值は普通，綿系の場 合は 0.1〜2mm程度, 毛の場合は 3 10 $\mathrm{mm}$ 程度で, その數值には相當の差が若るが; 繊維長代對する割合 をとつて考えれば，綿の場合1～5\%，毛の場合3～7\%
位の程度であり，兩者の間にそう大きな開きはない。 紡續性能を表現するものは繊維長，太るのみならず， 他の多数の性質の總合結果であるから, 唯單に纎維長 との關係に簡單な關係を求めることは無理であるが， 本結果は一般の紡績に對してb示唆を與えるととろが あるとを信ずる次第である。

交献

1. 大住吾八, 東京工業大學學報, 昭 9-10月, 618 651

2. 森山弘助, 綿スフ紡續, p. 17

3. 新井幸長，スフ紡績技惦敉程，p. 50

4. 西渴義堆, 繊學誌, 昭 $16-3$ 月

\title{
砂酸、纎維素に關する研究
}

\section{第 31 報 微 粉 碎 纎 維 の 硝 化}

渡邊貞良

\section{1. 緒}

湿酸中硫酸が多く含まれる場合の硝化反應に於ては 纎維不均一反隹1)とフィブリル不均一反應2) とが錯綜 して起る事は明である。本研究に於ては纎維構造を2 種の方法で破碎したラミー纎維に就て硝化を行ひ，そ の結果反應表面の增大に传て硝化速度が著しく增大寸 る事が認められた。且アセトン可溶度及びメタノール 可溶嘎子各硝化物儿就て馀驗し所期の結果が大體得ら れた。

\section{2. 織維の破碎法}

繊維の破碎は次の如き方法で行つた。

a）機械的破碎に低る場合 ラミ一瀻維をドライ・ア くスと共に Dewar摆中にて冷却し，48 時閒故置後鐵 製大型乳鉢に探り，ドラィ・アイ人と共に粉碎，更に 1 書夜 Dewar 叙中に入れ. 又取出して粉碎し, 最後 に又1回，都合 3 回粉碎を行つた。粉碎了りたる試料 は 1 回蒸留水にて洗滌し. 更に $1 \%$ 䔖酸》ーダにて洗 滌し, 更に 2 回蒸溜水にて充分洗桜後， $80^{\circ} \mathrm{C}$ 以下にて
乾燥し, $\mathrm{P}_{2} \mathrm{O}_{5}$ 乾燥器中に於て 1 書夜以上放置した。 以下との試料を單に粉碎狀繊維と名付ける。

b) ク゚リセリン中で高溫加熱處理した場合 シミー 繊維 $5 \mathrm{~g}$ を 300cc のグリセリン中に浸漬し, 250〜260 $\mathrm{C}$ で約与時間竟沸し，後充分水洗して乾燥し，之を粆鉢 で細粉した。との場合繊維はグリセリン中でフィブ 几分離を起し，極めて微細な狀態となる。第圆は(a) の機械的破碎化依つた粉碎狀纎維の顯徽鏡寫真である ( ×120)。この場合フィブリル分離は殆ど認められな い。

\section{第 1 圆 \\ 機械的破䖝に依る 粉碎狀繊維 \\ $(\times 120)$}

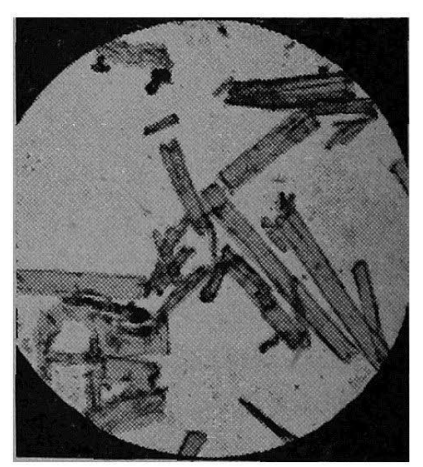




\section{3. 微粉碎襍維の硝化及び硝化物の性犋}

a) 粉碎狀纎維の硝化

粉碎狀瀻維を $0^{\circ} \mathrm{C}$, 硝酸 (S. G1.52): 硫酸(S. G1.84) $=1: 3$ 容量比の源酸で硝化した。但し湿酸倍量は 500 倍，其他の條件はすべて他の著者の報告と同樣であつ た。

硝化物の $\mathrm{N} \%$ ， × タノー儿可溶度，酸價及び醋酸ア ミ儿溶液の粘度を測定して第 1 表の結果を得た。

b）グリセりン處理盏維の硙化

a と同樣にして硝化した。但しこの場合極めて微粉 狀でするから硝化物はガラスフィルターで湿酸と分 離した。

硝化物の $\mathrm{N} \%$ ，×タノール可溶度，酸價及びアセ卜 ン可溶度及び其溶液の粘度を測定して第2 表の結果を 得大。

第 2 圆に粉碎狀ラミーとグりセリン處理ラミーの硝 化速度曲線を示した。

第 1 表 粉碎斨瀻維确化物の諸性算

\begin{tabular}{|c|c|c|c|}
\hline 硝化時間 & $\begin{array}{l}\text { 空素合有 } \\
\text { 量 }(\%)\end{array}$ & $\begin{array}{l}x \not \prime< \\
\text { 可溶度 }(\%)\end{array}$ & 酸儨 \\
\hline 1 時間 & 7.66 & 16.4 & 13.4 \\
\hline 24 㭙 間 & 12.65 & 10.9 & 13.0 \\
\hline
\end{tabular}

24 時間硝化物の醋酸アミ儿溶液の粘度 $\left(20 \pm 0.1^{\circ} \mathrm{C}\right)$

\begin{tabular}{cll} 
溶液の敳度 $(\mathrm{g} / \mathrm{l})$ & \multicolumn{1}{c}{$\eta_{s p}}$. & $\eta_{s p} / \mathrm{C}$ \\
\hline 1.27 & 0.977 & 0.770 \\
0.212 & 0.158 & 0.743 \\
0.112 & 0.0752 & 0.671 \\
2.40 & 3.76 & 1.565
\end{tabular}

第 2.表 グリセリン處理瀻維硝化物の諸性質

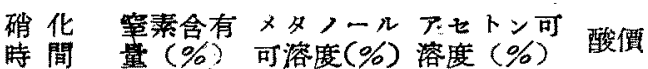

$\begin{array}{rrrrr}1 & 6.99 & 29.4 & 53.6 & 4.5 \\ \mathrm{~g} & 10.63 & 47.6 & 77.3 & 4.0 \\ 5 & 10.43 & 37.4 & 66.8 & 5.2 \\ 7 & 11.15 & 37.2 & 76.2 & 6.3 \\ 24 & 12.72 & 21.9 & 96.0 & 10.1\end{array}$

*註 未硝化物のメタノール可溶度として $7.2 \%$ を 得卡。

硝化物のアセトン溶液の粘度 $\left(20 \pm 0.1^{\circ} \mathrm{C}\right)$

\begin{tabular}{cccc} 
㗂化㭙間 & 溶液濃度 $(\mathrm{g} / \mathrm{l})$ & $\eta_{s q}$ & $\eta_{s t} / C$ \\
\hline 1 & 0.469 & 0.036 & 0.078 \\
3 & 1.616 & 0.116 & 0.072 \\
5 & 1.421 & 0.177 & 0.123 \\
7 & 1.750 & 0.232 & 0.189 \\
24 & 1.512 & 0.287 & 0.190
\end{tabular}

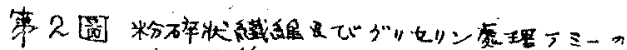
硝化線

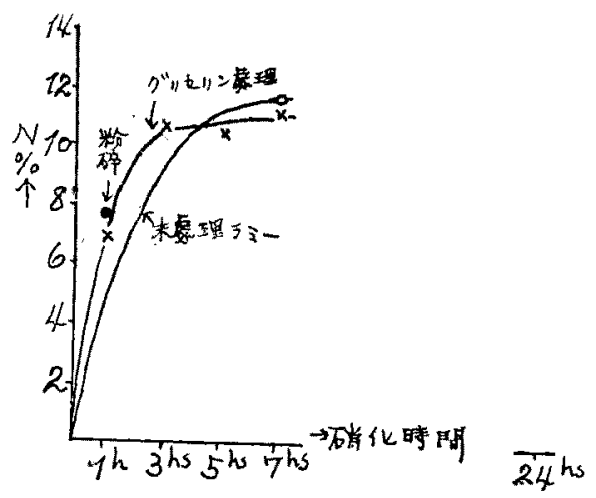

第2 圆には比較の䨓，天然ラミ一の同一の湿酸に依 る硝化曲線を畫いた。之等の比較から明な樣に犄棒狀 ラミーもグリセリン處理の微粉ラミ一夕共に末處理ラ ミ一の場合よりる極めて急速に硝化せられ，例へば 1 時間硙化物性共に，未處理ラミ一の2 時間硙化物より 高确化度を示し，3時間硝化のグリセリン處理フミ一 は4時閒硝化未處理ラミーと殆ど同程度のエステル化 度を有して居る。5時閒以後の硝化物てはか人る優越 は示されず, 反つて未處理のもののェステル化度の力 が大きい位でする。

初期のエステル化反應が極めて速なる理由は粉碎に 依て繊維棈造が破攘せられ，從て反㷳表面が擴大せら

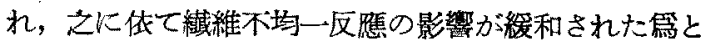
思はれる。

更に第3 圖に之等硝化物の空素含有量とメタノール 可溶度との關係を示した。
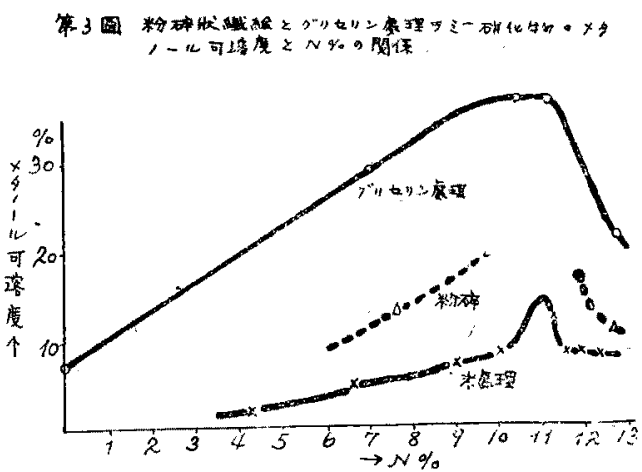

この圖から分る羕に，グリャリン處理及び粉辞狀ラ ミ一确化物の可溶度は何れる末處理ラミ一硝化物の夫 より大である。特にグりセりン處理のるのの值が大で あるが，このものは試料が極めて微粉狀であつて既に 未硝化の6のでょタノールに $7.2 \%$ 溶解する。從て

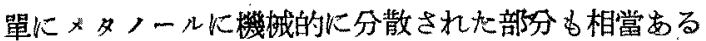


ものと思はれる。

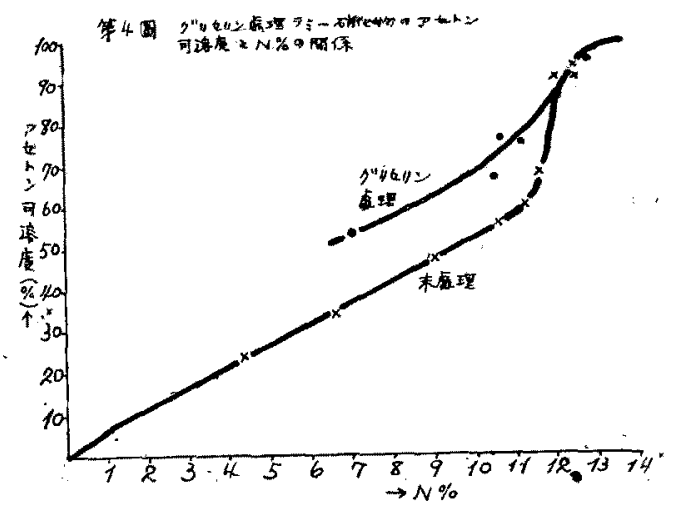

第4 圖はダリセリン虎理硝化物の广セトン可溶是と N\%との關係で西るが，この場合も米處理のものより 一般に大なる值で示される。等の原因は先に述べた 機践的分散の外に，幾分は其低重合度にb原因するの
であろろ。

\section{4. 總括}

瀻維檴造を機峨的に破碎したラミ一及ぴグリセりン 中で高盢加熱處理したラミ一湅粉を硫酸を多量に含む 湜酸を用ひて硝化し，その結果未處理タミ一の場合に 比し，反隹速度が增大寸る事を認めた。之等の結果は

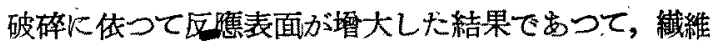
不均一反留が起つて居る事を意味する。硝化物のメタ ノール及びアセトン可溶度は未處理ラミ一硝化物さり

一般次高く，特にダリキりン處理の場合著しい。之等 は低需合度並に機械的分散に原因するものが大でする と思はれる。

文献

1) 著者，工化，昭 $19 ， 47,723$

2) 著者，工化，投稿中

\section{第 32 報硝化へミ繊維素の安定化}

\section{1. 緒言}

硝化一ミ瀻維素を蒸溜水を用ひて煮沸したる場合， 煮沸時間の經過と共に硝化物の收量, 安定度, 窒素含 有量及びアセトン及びメターール可溶度が如何に絡化 するかを追跡し，以てパルプ硝化物の煮沸安定化の場 合を推察した。

\section{2. 硝化及び安定化條件}

硝化用一ミ纎維素としては東洋レーヨン株式會社に 於て針葉樹パルプのマーセりゼーション閉液からアル カリ透析器を用ひてッーダ回收を行占場合, 逶析膜炕 附着线留する部分を用ひた。之等の分析結果其他化就 ては前報を參照されたい。

硝化は下詮 2 種の湿酸を用ひた。

\section{第 1 表 硝化用混㴗組成}

\begin{tabular}{ccccc} 
& & 硝酸 $(\%)$ & 硫酸 $(\%)$ & 水分 $(\%)$ \\
\hline 混 & 酸 I & .44 .4 & 54.4 & 1.2 \\
混 & 酸 II & 28.7 & 70.4 & 0.9
\end{tabular}

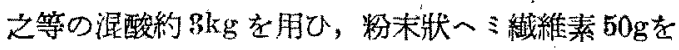
徐々に添加し，添加每炕激しく队容を㩭拌した。硙化

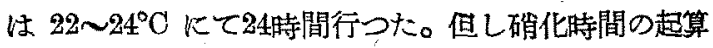

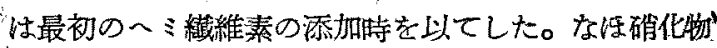

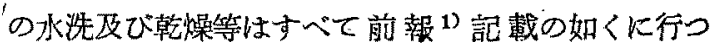
t施。

乾燥磎化一ミ緎維素は $5 \mathrm{~g}$ づ 21 內容のビーカー K分取し，豫め $90^{\circ}$ 以上K加熱せる蒸留水1了を加都 沸安定化を行つた。而して蒸㓎に低る液量の損失は常 に加熱蒸溜水の添加に侤て補ひ，11の液量を保持した

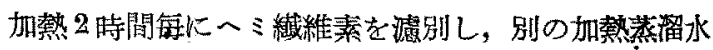
中に移して安定化を續けた。郎ちさ時間等に換水を行

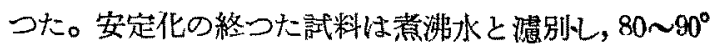
で恒量となる迄乾燥した。

\section{3. 實 驗 結 果}

かくして最高 100 時間の煮沸水安定化を行つた硝化 一ミ織維素の各に就て試料の收量(從て減量),安定度， 窒素含有量，アセトン及ぴメタノール可溶度を試驗し た。

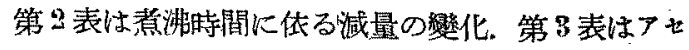
トン可溶度，第 4 表ばメターール可溶度. 第5表好空 素含有量, 第 6 表は $\eta p s / c$ 倠の等化を示すすのです る。 


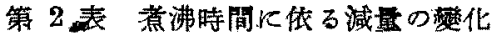

\begin{tabular}{|c|c|c|c|c|c|}
\hline 煮沸時閻 & 2 & 4 & 6 & 8 & 10 \\
\hline 試 科 I & 8.78 & 12.81 & 11.09 & 10.25 & 12.42 \\
\hline 試 科 II & 2.96 & 5.92 & 18.00 & 11.98 & 11.81 \\
\hline 㱳沸時間 & 20 & & & 50 & 100 \\
\hline 試 料 1 & $\div$ & 16 & & 20.20 & 25.08 \\
\hline 試 料 II & 12.92 & 11 & & - & - \\
\hline
\end{tabular}

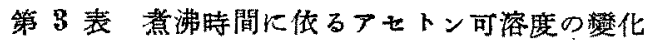

\begin{tabular}{|c|c|c|c|c|c|}
\hline 惹沸時間 & 0 & 2 & 4 & 6 & 8 \\
\hline 試 料 I & 80.0 & 83.4 & 89.3 & 89.0 & 96.1 \\
\hline 試 料 II & 86.4 & 91.5 & 95.8 & 95.6 & 94.2 \\
\hline 惹进特閒 & 10 & 30 & & 50 & 100 \\
\hline 武 料 & 95.7 & 97.9 & & .00 & $\cdot 100$ \\
\hline 䳝料 II & 99.8 & - & & - & - \\
\hline
\end{tabular}

第 4 表 煮沸特間に依るメタノ一几可溶度の變化

\begin{tabular}{|c|c|c|c|c|c|}
\hline 鯺进時間 & 0 & 2 & 4 & 6 & 8 \\
\hline 試 料 I & 45.2 & 45.3 & - & 45.4 & 46.1 \\
\hline 試 料 II & 44.0 & 38.2 & 39.0 & 39.1 & 40.0 \\
\hline 若进特間 & 10 & 30 & & 50 & 100 \\
\hline 試 料 I & 46.0 & 46.5 & & 46.0 & 58.1 \\
\hline 試 料 II & 42.8 & - & & - & - \\
\hline
\end{tabular}

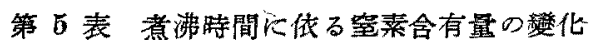

\begin{tabular}{|c|c|c|c|c|c|c|}
\hline 惹沸時間 & 0 & 2 & 4 & 6 & 8 & 10 \\
\hline 試料 I & 11.61 & 12.23 & 12.89 & 12.76 & 12.68 & 12.72 \\
\hline 試料 II & 12.43 & 12.68 & 12.98 & 12.96 & 12.88 & 12.80 \\
\hline 煮沸時閶 & & 30 & & 50 & & 100 \\
\hline 試 料 & & 12.68 & & 12.74 & & 12.71 \\
\hline 武 料 & II & - & & - & & 一 \\
\hline
\end{tabular}

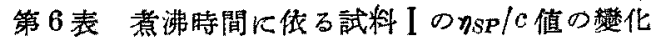

\begin{tabular}{lllllll} 
惹沸特間 0 & 2 & 4 & 6 & 8 & 10 \\
\hline
\end{tabular}

$\begin{array}{llllll}0.0158 & 0.0164 & 0.0153 & 0.0154 & 0.0152 & 0.0152\end{array}$

第 1 圆，第 2 圆に夫 3 試料 I，II の煮沸㭙間に依る 其他の值の蔹化を一括して示した。

者沸に侤る确化一ミ瀻維素の隇量は試料 I K於ては 最初の 4 時間，試料 【K於ては 6 時間目に約 $1.2 \%$ K荎

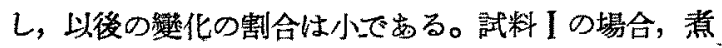
沸㭙間の延長上共に隇量は直線的に增加して來るが， 之は2時間每に換水する際，いちいち試料を滤過する 篇，損失となる部分が相虽多く，實際に煮沸水に溶出 する部分は比較的少いと思はれる。例人估試料 100 時 間意沸の場合，濾渦は50回行ふ事となり，滤紙に附着 して損失する量る相當大となる。從て事璂上惹泓水に

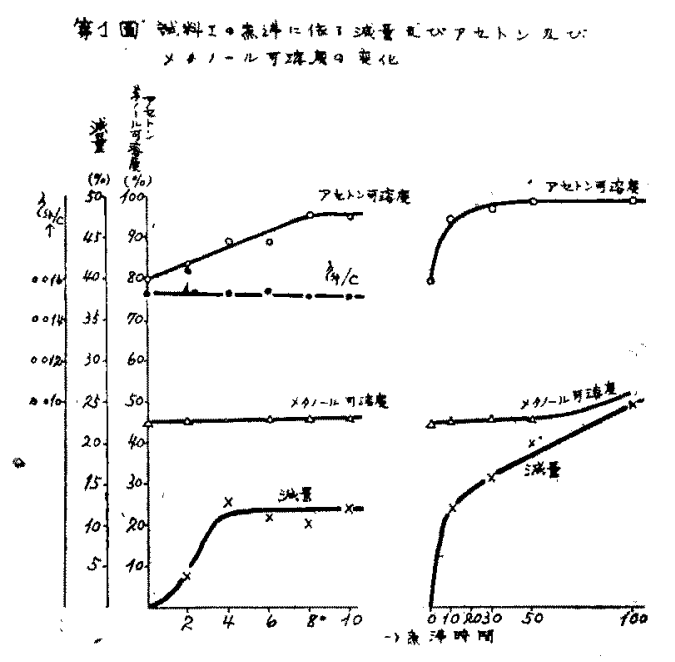

溶出するのは者沸時間のごく初期に於てのみである。 試料 II の場合は者沸㭙間30時間迄しか取らなかつたが， 6 時閒以後殆ど減量の增加は認められなかつた。

之等試料 I 及び II を通して㟟沸に依る減量が約 $12 \%$ である事は，原料のへミ瀻維素中のペントザン含量が 12.1\%である重と對比して考へると，大體硙化ペント

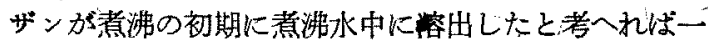

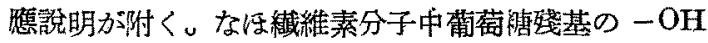
基は 3 個. ペントザン分子中ベントーズ㽝基の $-\mathrm{OH}$ 基は2個であるから．同一混酸で碙化したる場合，ぺ ントザン硝化物の窒素含有量は絾維素硝化物の夫より

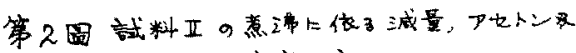

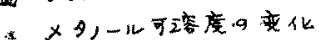

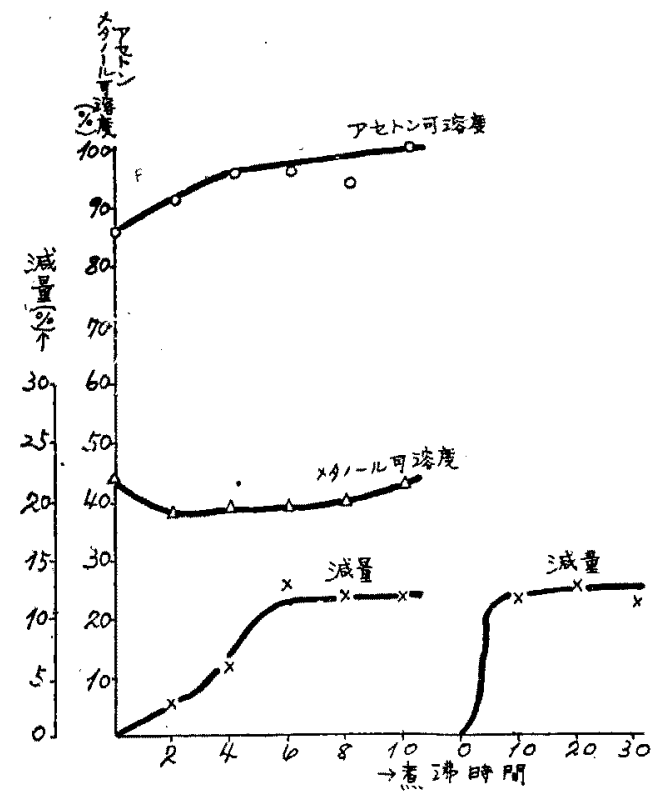




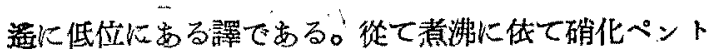
ザンの溶出が事實なら必然的に試䉼の窒素含有量は上 界する等でする。事實第 5 表の結果はこの踭想と一致 し，試料 Iでは煮沸4時間，試料【゙ては煮沸 6 時閐で 最高空素含有量を示し，其値は $13 \%$ 近ぐとなる。更に

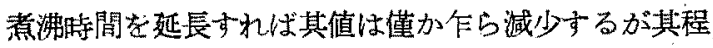
度は榣めて小である。郎ち硝化ベントザンの溶出は其 大部分が煮沸の初期化完了したと考へて差支へないと 思はれる。

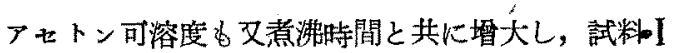
では 8 時間，試料 II では10時間で夫 $100 \%$ 完溶亡な る。之等る硝化ペントザンの煮沸水溶出に佐てアセト ン飞難搈性の硝化ペントザンが試料中より無くなり潮 次アセトン可溶度が增大したものと考入られる。なほ 硝化マンナンは Husemann に侤机ばアセトン可溶て 岁るとの事であるから2，乙の場合考慮する必要はな 1.

アャトン可溶度と反對にメタノール可溶度の變化は

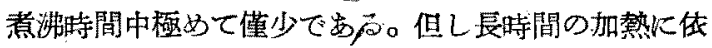
てや1霄大を示す。之等硫酸分比較的大にして水命の

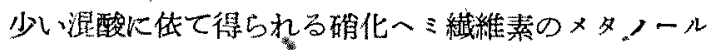
可溶度が. 含水量大なる注酸に伡て得られた硝化物の 夫に比して小でする理由を著者はさきに難溶性ペント

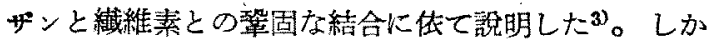
るにこの場合确化ペントザンの大部分が溶偝液に溶出 したと考へられる場合にも×タくール可溶性は殆ど向 上しない。との事はな浮難溶性ペントザンの微量が存 在し，之が溶解を阻止するとも考へられるが(高分子 物質では暦タからる例が存在する。'例人ば重合度 1700 のホリスキロールK0.002\%のギ・ビニル・メ゙ンゾー ルの混合は最早ペンゾールに對する溶解を許さない(4), な汪この場合の硝化物が極めてマクロ不均一反篧で田 來されたすのですり，從て硝化物は高硝化部分之低硝 化部分とが存在し，同れの部分る×ターールに對する 膨潤性が均一硝化物に比較してそしいる考へてb說明 が附く。

な注試料】の $\mathrm{nsP} / \mathrm{c}$ 值は煮沸 10 時間に到る，殆ど 變化しない。との事は安定戛理に传て硝化一、纎維素 の崩壤が殆ど起らない事を意味する。

更に各試料の安定度を試驗した。第，4 圖に試料 1 及び【の發火點, 酸僄，アーベル耐熱度の意泇時間に 伎る㘘化を示した。

之等の結果を見ると酸價は始め急激に減少し，㟟沸 6 時間で試料 I 及びII 共に 7 8 位の值となる。之等 末處理の試料の酸僄は夫了 46.7 及び78.4であるから 酸價に關する限り最初の数時間の著沸に依て吸着酸の 大部分は除去された譯である。乽沸に㑈る安定化は以

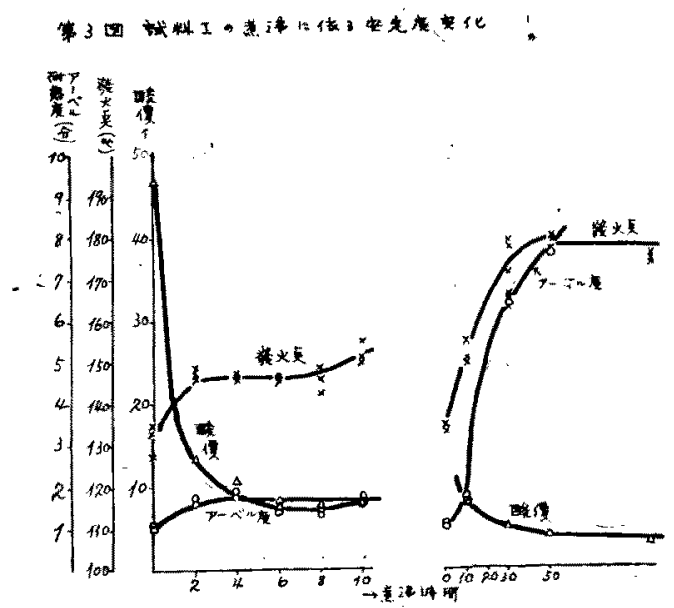

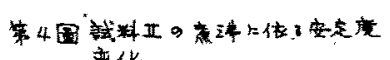

後緩慢となり試料 1 ては 100 時間蓄㴶て 3.4 となる。登火點

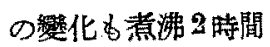

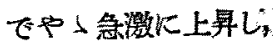

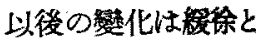

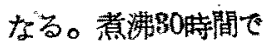
發火區域 II 的登火 區域 I K向上する が，安空化の模柱性 大體木棉及びッンタ 一硝化物の堨合と大 差がない，6試料 【K 裁て求めたアーヘル 耐熱度の結果は大體 發火點及び酸偠の傾向と一致する。な的醌酸，硝酸搌 酸で硝化して得大硝化一ミ繊維素が極めて安定である 事は既に别報で述べたが7，との事から Holzpolyse の硝化物は本來安定でするが硫，硝酸湜酸中、モ二次的 に不安定化を起原因（硫酸或は夫见關係する物筫） が介在すると考へた。硝化一ミ繊維素を不安定化なら しめる原因は從て遊離酸，吸着酸，硝化ペントザンの 硫酸結合物，繊維素硝化物の硫酸結合物等が考へられ るが劣沸に位て先ず酸の遊離が起り，头で硝化ペント ザンが溶出し，最後に繊維素及びアンナ゙ン諉導體のみ が䖪り，而して其安定化の樣相は至く天然械維素硝化 物の場合と一致する。一般にバルプ碙化物の場合はへ

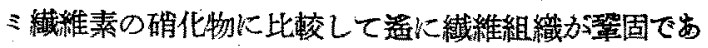
るから惹沸に依る硝化ベントザンの溶出等も幾分困難 と思はれるが，大體の傾向は一致すると考へられる。

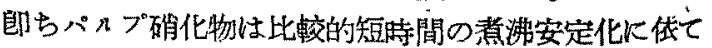
硝化ペントザシの溶出が可能であらう。而して爾後の 安定化は全く天然繊維素硝化物例一ば精製ラミ一或は. 精製脫脂棉硝化物の場合と略同一と考へられる。 


\section{1. 總括}

2 種の硫，确湜酸を用ひてつミ繊維素を硝化して得 たる硝化物を蒸溜水中で㶨沸安定化した結果。

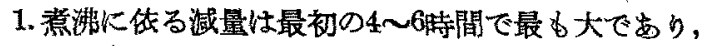
後の變化は極めて小である。其減量\%は硝化ペント ザンの含量と一致し，この嘗沸期間中に确化ペントザ ンの溶出が考へられる。

2.アセトン可溶度るとの期間比上荓し，100\%に達 し，同樣アたトン難溶性の确化ペントザンの溶出に侤 て說明される。

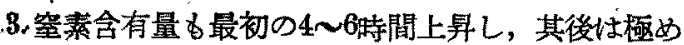
て䜌が減少する。始めの上氧は硝化ペントザンの除 去化传るるのと思はれる。

4.抽出酸分は最初の 2 時間で極めて大であり，惹沸 に低て急速に除去される事が分つた。

5. ×タノーл可溶度の䌝化は安定化中を通して僅少 である。

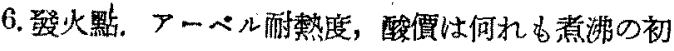
期比上昇し. 其後の變化率注僅かでする。初期の上氧 は遊離酸, 吸着酸分の除去と硝化ペントザンの溶出に 依るものと考へられる。以後の安定化の樣相は木棉及， びリンター等の硝化物の場合と略一致する。

本報告を硝酸繊維素の安定性 (第8 報) とする。

交献

1) 湆者。工化．昭19，47，765

2) Husemann, J. Rrakt. Chem. 1940, 155, 241

3) 著诸. 工化. 昭 $19,47,769$

4) H. Staudinger u. E. Dreher; Ber, 1986, 69, 1729 ; H. Staudinger, Zur Entwicklung der Chemie der Hochpolymeren, Berlin : Verlag Chemie. 1937

5) 著者. 工化. 炤 $17,45,668$

6) 著者. 工化。昭 $19,47,776$

7) 著者. 工化，昭 $19,47,772$

（昭和 23 年 10 月 5 日受理）

有機液體孔隙の毛管吸水現象

\section{第· 2 報 各種液狀有機物質の毛管吸水能力試驗}

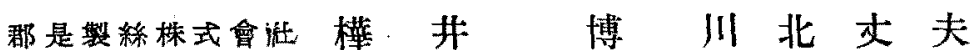

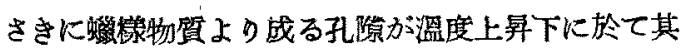
融點附近より顯著に毛管吸水性を發現する狀況を報じ

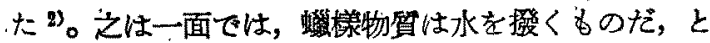
され易い事に對して，但し其は物筫が固態の場合に限 る，との註釋を附加した事になるが他面では，物質が 液悲の場合には一般に水を毛管吸收する，との類推を

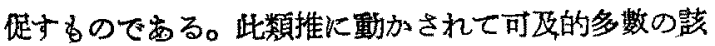

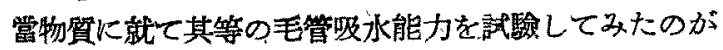
之でる。

\section{霓 驗之 部}

\section{I 毛管农水能の訪價方法}

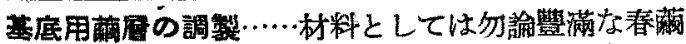

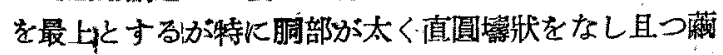

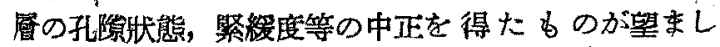
い。前報と同要領て之を處理し $300 \mathrm{mg}$ 㑧型脫蠗藏層
を 300 偭程作る。但し此場合恃袋型の底部に圆孔を穿

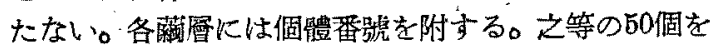
一組として各被檢花體孔嚐の毛管吸水能を統計的に訣 價するものとし，一組の觀测終了每に風乾一要すれば 2 日関×ーテル洗潾一次の觀測に再使用, の要領を繰 返しつ〉6 組 300 個の荋臂を交互に適當に供試するも のとする。因みに使用衡器は $500 \mathrm{mg} ト$ トシシン称が 最も便利に゙る。

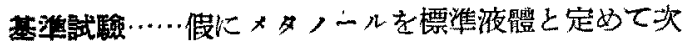

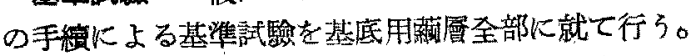

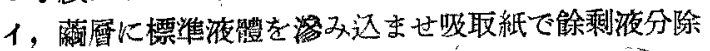

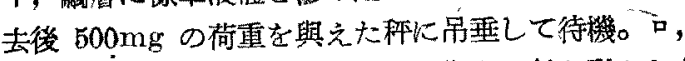
液體揮散に件引荡層重の輕減が平衡指示針を動かし其 本衡狀熊を告る瞬間を合圖に手早く藏臂を裝置に仕込

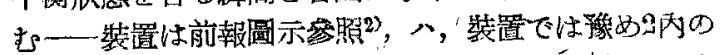

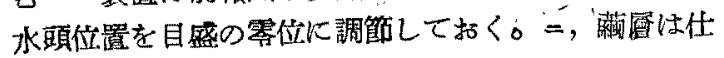

